\title{
Application of Solar energy for sustainable Dairy Development
}

\author{
Deepak D Desai ${ }^{1}$; J.B. Raol' ${ }^{2}$ Sunil Patel ${ }^{3}$; Istiyak Chauhan ${ }^{2}$
}

\begin{abstract}
:
At the time of independence milk production in India was only 17 million tones per annum. Today India has become number one in milk production, producing 127 million tones per annum with approx. $20 \%$ of the total milk production is handled by the organized sectors. Dairy and food industries are fast growing industries and day-by-day newer technologies are being introduced to get better quality of foods. Use of conventional energy is common practice for major processing of milk. At present all most all dairy operations are performed using grid supply with diesel gen-set as backup. Milk procurement system has changed in India and now milk is being procured by maintaining cold chain to improve its microbial quality. The village level co-operative societies for milk collections are provided by bulk milk coolers operating on conventional grid supply of electricity and in case of unavailability of electric supply diesel generator sets are provided for cooling the milk. To overcome the problem of continuous grid supply of electricity and diesel generator sets, solar based refrigeration system for milk cooling at society level is quiet feasible. Most of the milk processing operations, room conditioning for milk product packaging and cold stores for milk \& milk products are operating on grid electric supply. To overcome problem of peak load penalty, the part load can be shared by solar based vapour absorption system for such operations. The use of solar energy in the dairy is generally found for hot water supply to boiler, hot water generator for processing of milk or for CIP cleaning. The field level application of solar based refrigeration system for milk cooling and solar based vapour absorption system for commercial application for milk and milk related cooling operations and for room conditioning for cold stores and packaging rooms for milk and milk products are minimum. There is an urgent need to develop commercially viable solar based refrigeration system for such applications.

The existing knowledge of refrigeration \& air conditioning and solar energy will be applied to design and develop energy efficient solar based refrigeration system for milk cooling at village level society and solar based vapour absorption system for milk and milk related cooling operations and for room conditioning for cold stores and packaging rooms for milk and milk products, to reduce peak load penalty. Use of solar energy has great scope for its commercial use in the dairy processing operations as well as to design and develop solar based refrigeration systems for dairy industry.
\end{abstract}

Key Words: energy, refrigeration, renewable, dairy

1. M.Tech Scholar, Dairy Engineering Department, SMC College of Dairy Science, AAU, Anand. India

2. Assistant Professor, Dairy Engineering, SMC College of Dairy Science, AAU, Anand

3. Associate Professor \& CCPI- Business Planning \& Development Unit-AAU (ICAR-NAIP-I

Project), Dairy Engineering, SMC College of Dairy Science, AAU, Anand, India 


\section{Introduction}

India is among the fastest growing dairy nations in the world. With increase in population, and enhancement in lifestyle of people, demand for the dairy and food products is increasing day by day. With increase in product demand, energy demand as well as well commercial energy consumption has been increasing at $\sim 6 \%$ during last two decades; India ranking 5 th in the world. $49 \%$ of total energy is consumed in Industry. Import dependency at present, is $9 \%$ for coal, $77 \%$ for crude oil and petroleum product and $31 \%$ for natural gas. (Desai and Zala, 2010)

Today, major electricity generation takes place at central power stations which utilize coal, oil, water, gas or fossil nuclear materials as primary fuel sources. They are not renewable-limited-like every one earth has limitation to regenerate, less efficient (65-75\%) and expensive. Renewable energy is that energy which comes from the natural energy flows on earth. Unlike conventional forms of energy, renewable energy will not get exhausted. Renewable energy is also termed as "green energy", "clean energy", "sustainable energy" and "alternative energy" (Date, 2010). For production of energy we are using Petroleum (39\%), Natural gas $(23 \%)$, Coal $(23 \%)$, Nuclear $(8 \%)$, Renewable energy sources $(8 \%)$ in different proportion. Different types of renewable energy are: Solar energy (1\%); Wind energy (0.5\%); Biomass energy (43\%); Hydropower (50\%); Geothermal (5\%); The Sun is a reliable, non-polluting and inexhaustible source of energy, with overcome of all above shortfalls; it will never get exhausted ever. India lies in the sunny regions of the world. As concern to Indian scenario, we receive 5 to $7 \mathrm{kWh} / \mathrm{m}^{2}$ of solar energy for 300 to 330 days in a year, which is sufficient to set up $20 \mathrm{MW}$ solar power plants per square kilo meter land area (BEE, 2010)

The highest annual radiation energy is received in western Rajasthan while the north-eastern region of the country receives the lowest annual radiation. We can use solar energy in dairy operation like cooling, heating, lighting, pumping, drying, electrifying, steam generation, etc,. In order to use this technology in a costeffective manner it is essential to understand the resource, the component and system aspects of the PV (photovoltaic) plant and also to have a load served by efficient end-use equipment with a high-value service (Jenkins, 1995).

\section{History}

Solar technology is not new. Its history spans from the 7th Century B.C. We started out concentrating the sun's heat with glass and mirrors to light fires. Today, we have everything from solar-powered buildings to solar powered vehicles. 1954 Photovoltaic technology is born in the United States when Daryl Chapin, Calvin Fuller, and Gerald Pearson develop the silicon photovoltaic (PV) 
cell at Bell Labs - the first solar cell capable of converting enough of the sun's energy into power to run everyday electrical equipment. As of 2012, the history's largest solar energy plant is the Golmud Solar Park in China, with an installed capacity of 200 megawatts. This is arguably surpassed by India's Gujarat Solar Park, a collection of solar farms scattered around the Gujarat region, boasting a combined installed capacity of 605 megawatts.

\section{Different Devices to use solar energy.}

\subsection{Photovoltaic Plats:}

Solar energy can be transformed to electricity by using photovoltaic (PV) devices. PV devices convert light energy into electrical energy through photoelectric effect, as French physicist Edmond Becquerel discovered as early as 1839. Individual PV cells (or so-called solar cells) are electricity-producing devices made of semiconductor materials. Among many types of solar cell material, silicon wafers, polycrystalline thin films, and single-crystalline thin films represent the typical solar panel material (Broos, 1996). Bulk silicon was used to make some of the earliest PV devices. Single crystal silicon-wafer-based PV cells plated on the glass are the more widely used compared to other materials, but their efficiency is relatively low and their costs are relatively high. With the advent of the transistor and accompanying semiconductor technology, the various thin-film technologies have been developed. These thin film technologies have reduced the manufacturing cost from that of bulk materials, and their efficiency exceeds those of bulk silicon wafers by having a multilayer thin film structure. Polycrystalline thin film has efficiency between $10 \%$ and $17 \%$ (Wu, 2004). Single-crystalline thin film using multi-junction solar cell structure is the most efficient one between $15 \%$ and $20 \%$. The latest development for the single-crystalline film using a multi-junction solar cell structure resulted in a world-record conversion efficiency of $41 \%$ in an optical concentrator solar cell produced by Boeing-Spectrolab (Fthenakis and Alsema, 2006). This PV device can used for storing solar energy and to utilize in the dairy plant for different unit operation heating of water and air, pasteurization, pumping, refrigeration plant.

\subsection{Solar Ponds}

A solar pond is a body of water that collects and stores solar energy. Solar energy will warm a body of water (that is exposed to the sun). Water warmed by the sun expands and rises as it becomes less dense. Once it reaches the surface, the water loses its heat unless some method is used to trap it. The design of solar ponds reduces this energy loss to store the heat collected by the pond. They can operate in almost any climate. A $6000 \mathrm{~m} 2$ solar pond was constructed at Bhuj in India in the premises of a milk processing dairy plant. The 
pond attained a maximum temperature of 99.88 oC. Hot water supply to the dairy started in September 1993. The total cost of construction of the Bhuj Solar Pond was US $\$ 90,000$ (1997 prices), including heat exchanger and piping etc., corresponding to a unit cost of US $\$ 15$ (Kumar and Kishore, 1999).

\subsection{Solar Cooker}

A solar cooker, or solar oven, is a device which uses the energy of sunlight to heat food or drink to cook it or sterilize it. The vast majority of the solar cookers presently in use are relatively cheap, low-tech devices. Because they use no fuel and cost nothing to operate, many nonprofit organizations are promoting their use worldwide to help reduce fuel costs for low-income people, reduce air pollution and slow deforestation and desertification, caused by use of firewood for cooking. Solar cooking is a form of outdoor cooking and is often used in situations where minimal fuel consumption is important, or the danger of accidental fires is high (Resch, 2007). A heat pump is a device that transfers thermal energy from a source to a sink that is at a higher temperature than the source. Thus, heat pumps move thermal energy in a direction which is opposite to the direction of spontaneous heat flow (Lorentze, 1993).

\section{Solar energy use in dairy Industry}

Davidson and Oni are of the opinion that since the fossil and nuclear fuels are depletable energy sources that over dependence on them will lead to a severe energy crisis as the World's energy demands remain doubtful. Effective management, conservation, exploration and utilization of the country's energy sources are required (Minijibar and Abubakar, 1991). Pragmatic efforts have been made to construct photovoltaic (PV) modules which provide simple, reliable and independent electrical power source at remote locations (Oparaku and Iloeje, 1991). This can be seen in the areas of solar water heating for dairy farms and micro irrigation (Essandoh-Yeddu, 1993).In Ghana solar dryers were used for drying of mainly okra, pepper and maize. Drying took on an average three days with the solar dryers compared to one week with sun-drying. (Bross, 1996)

\subsection{Solar energy for cooling purpose}

Hot weather days cause often large fresh milk defect in southern developing countries dairy farms as well as in rural areas where there is a scarcity of energy sources that could run cooling equipments. Consequently the possibility to use solar cooling starts to be considered an attractive solution. In solar electric cooling, dc power produced by the solar PV devices is supplied either to the Peltier cooling systems or to the vapour-compression systems with a 
dc compressor motor. Since the solar electrical cooling systems rely on the electricity supplied by the PV devices, the overall system efficiency is predominantly determined by the efficiency of the PV devices. The overall energy conversion efficiency of the solar-powered vapour-compression cooling systems is obtained from the energy conversion efficiency of the PV cell and the COP (co efficient of performance) of the vapour-compression system. Similarly, the overall energy conversion efficiency of the grid-powered vapour-compression system is obtained from the energy conversion efficiency of the grid power plant and the COP of the vapour-compression system. Klein and Reindl (2005) investigated the issues of matching the electrical characteristics of the compressor motor with the power produced by the PV cells.

\subsection{Solar based Refrigeration plant:}

The system is intended for refrigeration at $5^{\circ} \mathrm{C}$ in hot climates, and is composed of: medium temperature collector, single effect water ammonia absorption chiller and cold storage. The peculiarity of the configuration is the high temperature difference between the chilled refrigerant temperature, about -5 ${ }^{\circ} \mathrm{C}$ (in consequence of using ice storage) and the condenser temperature (ambient temperature, which could exceed $35^{\circ} \mathrm{C}$ ). In these conditions, the absorption chiller must be driven by a medium temperature heat source (i.e. parabolic trough collector). Moreover, the selected chiller is directly air cooled, and has the main advantage of having no water consumption, low maintenance work and no legionella problems (Ayadi, et.al,. 2008).It used for the chilling of milk in bulk milk cooler. It also used to run a vapour absorption system for refrigeration plant and maintain cooling system. A power stored in battery at use for the run an air conditioner. (Ishaku, 1990)

\subsection{Solar Water Heating}

Solar water heating industry constitutes the majority of solar thermal applications in both domestic and industrial sectors. They are considered as the most cost-effective alternatives among all the solar thermal technologies currently available. SWH systems are now in commercialized stage and very mature in many countries in the world. Since 1980, utilization of SWHs has been increased with 30\% annual growth rate (Langniss and David, 2004).SWHs are usually composed of solar collectors and a storage space. It works on the basis of the density inequality of hot and cold water or thermo syphon. In colder countries, integrated collector/ storage SWHs is more common because of simple and compact structure. Batch solar collectors are more suitable for compensating sun radiation limitations in the evening and afternoon (Li, 2007). SWHs and solar space heating systems. Solar thermal can be applied in milk, cooked meats (sausage and salami) and brewery industries at medium temperature for washing, 
cleaning, sterilizing, pasteurizing, drying, cooking, hydrolyzing, distillation, evaporation, extraction and polymerization. (Benz, et.al,. 1999)

Nine units of $169 \mathrm{~m} 2$ of ARUNTMare installed by Clique Developments Ltd., Mumbaiin the sectors of hospitality, dairy, chemical processing and auto manufacturing for delivering dry saturated steam up to 8 bar(g) (IBR approved system) or pressurized hot water. Before this, $160 \mathrm{~m} 2$ unit of ARUN ${ }^{\text {TM }}$ was designed and installed by Clique Developments Ltd. for pasteurisation of milk at Mahanand Dairy, Latur. As a result, the dairy does not need to fire the boiler on sunny days.

Mahanand dairy (Maharashtra) is using solar water heating system (25000 LPD) since 1990, which was commissioned with the assistance of department of Non Convectional Energy Source and Maharashtra Energy Development Agency. The water is heated from $30^{\circ} \mathrm{C}$ (ambient temp.) to $85^{\circ} \mathrm{C}$ with the help of solar water heating system, which is used for boiler as feed water, etc. This result in to saving of $200-250$ lit furnace oil per day, with monetary savings of about Rs. 7 lakh per annum.

\subsection{Solar heating for Steam generation in dairy}

Low temperature steam is extensively used in sterilization processes and desalination evaporator supplies. Parabolic trough collectors (PTCs) are high efficient collectors commonly used in high temperature applications to generate steam. PTCs use 3 concepts to generate steam (Kalogirou, et.al,. 1997) the steamflash, direct or in situ and the unfired-boiler. In the steam-flash method, pressurized hot water is flashed in a separate vessel to generate steam. (Kreetz, et.al,. 2000). Oil fired Boiler is feed with normal water for the routine operation. On installation of solar water heater, the feed water of the Boiler raised to $67^{\circ} \mathrm{C}$ from $27^{\circ} \mathrm{C}$. On inspection and verification it is found that an average 3000 lit of feed water being utilized per day. Due to this the thermal load saving to the extent of $120000 \mathrm{kCal} /$ day saved which amounts to 4774.20 lit of Furnace oil saved per annum. The Total investment was of Rs. 3.82 Lakhs and the cost savings was of Rs.1.57 Lakhs in the same year (BEE, 2010).

\subsection{Solar Drying in Dairy operation}

Solar drying and dehydration systems use solar irradiance either as the solely power supply to heat the air or as a supplementary energy source. Conventional drying systems burn fossil fuels for their performance while the solar dryers take advantage of sun irradiation for drying and dehydration processes in industries such as bricks, plants, fruits, coffee, wood, textiles, leather, green malt and sewage sludge (Schnitzer, et al..2007). 
They are categorized into 2 main groups: high and low temperature dryers. Almost all high temperature dryers are currently heated by fossil fuels or electricity but low temperature dryers can use either fossil fuels or solar energy. Low temperature solar thermal energy is ideal for use in preheating processes as well (Ekechukwu and Norton, 1999).Drying of milk powder, due to the high constant energy demand, is another important consumer. In the production, milk and whey are spray-dried in huge towers with air, which is heated from 120$180^{\circ} \mathrm{C}$. The drying process can have a running time up to about $8000 \mathrm{~h}$ per annum (Benz, et.al,. 1998).Solar energy is used mainly for the preheating of air which supplied to the air heater. It increases temperature of air $35^{\circ} \mathrm{C}$ to $80^{\circ} \mathrm{C}$ by use of solar energy. It reduces the load of air heater, cost saving, less pollution of air.

\subsection{Solar energy for pumping Dairy Fluids}

Solar pumping is one of the most important applications of PV in India. An SPV pump is a DC or AC, surface-mounted or submersible or floating pump that runs on power from an SPV array. It may use to run a hot water pump, chill water pump, milk pump and CIP (cleaning in place) pump. The array is mounted on a suitable structure and placed in a shadow free open space with its modules facing south and inclined at local latitude. A typical SPV pumping system consists of an SPV array of 200-3000 W capacity, mounted on a tracking/non-tracking type of structure. The array is connected to a DC or AC pump of matching capacity. SPV pumps are used to draw water for irrigation as well as for drinking. The SPV array converts sunlight into electricity and delivers it to run the motor and pump. The water can be stored in tanks for use during non-sunny hours, if necessary (Date, 2010).

\subsection{Solar energy to lightning Dairy offices and premises}

SPV lighting systems are becoming popular in both the rural and urban areas of the country. In rural areas, SPV lighting systems are being used in the form of portable lanterns, home-lighting systems with one or more fixed lamps, and street-lighting systems. A solar street-lighting system (SLS) is an outdoor lighting unit used to illuminate a street or an open area usually in dairy, garden, road approach to dairy and chilling centre. A CFL (compact fluorescent lamp) is fixed inside a luminary which is mounted on a pole. The PV module is placed at the top of the pole, and a battery is placed in a box at the base of the pole. The module is mounted facing south, so that it receives solar radiation throughout the day, without any shadow falling on it. A typical street-lighting system consists of a PV module of $74 \mathrm{~W}$ capacity, a flooded lead-acid battery of $12 \mathrm{~V}, 75$ capacity, and a CFL of $11 \mathrm{~W}$ rating. This system is designed to operate from dusk to dawn (that is, throughout the night). The CFL automatically lights up when the 
surroundings become dark and switches off around sunrise time. The cost of a SLS is about Rs 19000 (Date, 2010).

\subsection{Solar Energy for Electrifying (Electric Fences)}

Solar Electric fences are widely used in dairy to prevent stock or predators from entering or leaving an enclosed field. These fences usually have one or two 'live' wires that are maintained at about 500 volts DC. These give a painful, but harmless shock to any animal that touches them. This is generally sufficient to prevent stock from pushing them over. These fences are also used in wildlife enclosures and secure areas. They require a high voltage but very little current and they are often located in remote areas where the cost of electric power is high. These requirements can be met by a photovoltaic system involving solar cells, a power conditioner and a battery. (Carr, et.al,. 1999)

\section{Conclusion}

India has huge availability of Green energy and less amount of non renewable sources forces us toward solar energy. India has the potential of generating more than 100000 MW from non-conventional resources. Up to June 30 2008, the electrical power generation by conventional resources has reached $12,194 \mathrm{MW}$, which is about $8.4 \%$ of total installed electrical power generation capacity. We can use solar energy in dairy industry and chilling centre for cooling purpose, for heating of water, for steam generation, for solar drying, for pumping dairy fluid, for lighting and for electric fencing.

India has sufficient amount of sunshine that favours solar energy investments. Investment in solar energy technology should be encouraged as the merits include: pollution free environment, free renewable and energy source, high reliability and low maintenance costs. Most of the milk processing operations, room conditioning for milk product packaging and cold stores for milk \& milk products are operating on grid electric supply. To overcome problem of peak load penalty, the part load can be shared by solar based vapour absorption system for such operations. The use of solar energy in the dairy is generally found for hot water supply to boiler, hot water generator for processing of milk or for CIP cleaning. The field level application of solar based refrigeration system for milk cooling and solar based vapour absorption system for commercial application for milk and milk related cooling operations and for room conditioning for cold stores and packaging rooms for milk and milk products are minimum. There is an urgent need to develop commercially viable solar based refrigeration system for such applications. 


\section{References}

A-Report of BEE on Energy Conservation Achievements; Raichur, Bellary and Koppal district co-operative milk Producers Societies union limited, Bellary Dairy, Karnatak,.BEE, 2010:118

Ayadi, O.; Doell, J.; Aprile, M.; Motta, M. and Nunez, T.(2008). Solar cooling system discription, Solar energy cools milk:2

Benz, N.; Gut, M. and Rub, W.(1998). Solar process heat in breweries and dairies. In: Proceedings of EuroSun, Portoroz, Slovenia.

Benz, N.; Gut, M. Beikircher, T. (1999). Solar process heat with non-concentrating collectors for food industry. Proceedings of Solar World Congress.1209-1214.

Broos, P. (1996). Solar cells as optical systems: a matter of computation. Delft University of Technology Science researchbulletin. 4:8-12.

Carr, A., Fletcher, S., O'Mara, K. and Rayner, M. (1999). Solar cell principle and applications. Australian CRC for renewable energy ltd.

Date, V. (2010). Financial feasibility of solar power project with reference to rural electrification of 39 talukas in Karnataka, By NICMR

Davidson, I. E. and Oni, J. O. (1991) Energy conservation strategies and alternatives resources for Africa, Nigerian Journal of Renewable Energy. 2(1):85-88

Desai, H.; and Zala, A.; (2010) An overview on present energy scenario and scope for energy conservation in Dairy Industry. National Seminar on 'Energy Management and Carbon Trading in Dairy Industry

Ekechukwu, O. V.; Norton, B. (1999). Review of solar-energy drying systems II: an overview of solar drying technology. Energy Conversion and Management, 40:615-55.

Essandoh-Yeddu, J. J. (1993) Prospects for using solar energy power systems to meet energy requirements of agricultural facilities located in remote areas. Proceeding of National Energy Symposium $\mathbf{5}$

Fthenakis, V. M. and Alsema, E. (2006). Photovoltaics energy payback times, greenhouse gas emissions and external costs: 2004-early 2005 Statut, Progress in Photovoltaics: Research and Applications 14: 275-280.

Ishaku, B. G. (1990) Solar energy for power generation, Nigerian Journal of Renewable Energy 1:29-36

Jenkins, N. (1995). Photovoltaic systems for small-scale remote power supplies. Power Engineering Journal, 9(2):89-96.

Kalogirou, S.; Lloyd, S. And Ward, J. (1997). Modeling optimization and performance evaluation of a parabolic trough collector steam generation system, Solar Energy; 60(1):49-59.

Klein, S. A. and Reindl, D. T. (2005). Solar refrigeration, ASHRAE Journal, 47(9):26-30.

Kreetz, H.; Lovegrove, K. and Meike, W. (2000). Solar PACES-Solar Thermal Concentrating Technologies, Industrial Statistics :121-129.

Kumar, A. and Kishore, V. (1999). Construction and operational experience of a $6000 \mathrm{~m}^{2}$ solar pond at kutch, india, Solar energy, 65(4):237-249

Langniss, O. and David, I. (2004) Solar water heating: a viable industry in developing countries, 5:18-21.

Li, Z.; Guo-Qiang, Z.; Dong-Mei, L.; Jin, Z.; Li-Juan, L. and Li-Xin, L. (2007) Application and development of solar energy in building industry and its prospects in China. Energy Policy; 35:4121-4127.

Lorentze, G.(1993) Revival of carbon dioxide as refrierant, Internation, journal of refrigeration, 17(5):292-301

Minijibar, Y. A. And Abubakar, M. (1991) Use of photovoltaic solar energy for battery charging. Nigerian Journal of Renewable Energy10:77-84 
Oparaku, O. U. and Iloeje, O. C. (1991) Design considerations for a photovoltaic-powered waterpumping facility in a rural village near Nsukka, Nigerian Journal of Renewable Energy 10:64 69.

Resch, Rhone, and Kaye, N (2007) Giving Life with the Sun: The Darfur Solar Cookers Project, UN Chronicle, 65(1)

Schnitzer, H.; Christoph, B. and Gwehenberger, G.; (2007). Minimizing greenhouse gas emissions through the application of solar thermal energy in industrial processes.Approaching zero emissions, Journal of Cleaner Production 15:1271-1286.

Wu, X. (2004) High-efficiency polycraystalline CdTe thin-film solar cells, Solar Energy; 77(6):803814. 